\title{
MARGARYAN GOR
}

\section{SOME DETAILS ABOUT TIMUR LANG'S LAMENESS AND ORIGIN}

The general point of view of Timur's origin is the following: Tīmūr ibn Tarağå was born in 1336 (or 1334) in the village Khoja llğar of the district Kesh ${ }^{1}$ in Mawarannahr, by the origin he was from turkified Mongolian tribe Barlās. He is known as Timur Lang, Tamerlane, Tamburlaine, Temir Aksak², which means Lame Timur or Lame Iron: according to ibn 'Arabshah, his name was Tìmūr, which in other languages (probably in Turkish or Persian) pronounced as Tamūr or Tamrlank/Tamarlank and "he is the Iron ibn Tarağă in Turkish"3. Besides this explanation (Tīmur-Iron), another etymology of Timur's name we find in the autobiographical memoirs of Timur: according to The Mulfūzat after Tīmūr's birth his father went to shaykh Shams al-Din al-Fakhuri to choose a name for his son ${ }^{4}$. Shaykh opened Qur'an and read the $16^{\text {th }}$ ayat of $67^{\text {th }}$ surah "Do you feel secure that He who [holds authority] in the heaven would not cause the earth to swallow you and suddenly it would sway (tamūru)?"5. Consequently, this word (tamūru) is in the base of the name. Of course, it is an invented etymology, but this surah from Qur'an is not choosen accidentally-it is the surah al-Mulk (The Sovereignty), and it is important fact of legalization by

\footnotetext{
1 The modern town Shahrisabz in Uzbekistan.

2 "Повесть о Темир Аксаке. Памятники литературы Древней Руси: XIV-середина XV века". Москва, 1981, стр. 230."...прозван был Темир Аксаком, ибо Темир означает железо, а Аксак-хромец, так в переводе с половецкого языка объясняется имя Темир Аксак".

3 Ibn 'Arabshāh, 'Ajā'ib al-maqdūr fĩ akhbār Tìmūr, al-ma'rūf bi-Tārìkh Tîmūrì, 1868, lithographed edititon, p. 5. St'u 'umu, The Timurnamah or Ajayabul Maqdur Fi Akhbar-i Timur (in Arabic), edited by H.S. Jarrett, Calcutta, 1882, p. 3.

4 The Mulfuzāt Timūr or Autobiographical Memoirs of the Moghul Emperor Timūr, translated by Abu Talib Hussyni, Charles Stewart, Holborn, 1830, p. 21.

5 al-Qur'ān, 67:16.
} 
Qur'an Tìmū's coming to the power.

The Persian historian of Timurids-Sharaf ad-Dīn 'Alī Yazdī writes that "in the year of Mouse of Mongols on the 25 th month Sha'ban, on Tuesday (on the $8^{\text {th }}$ April in 1336) Teqina khatun and amir Tarağai gave birth to Timur in the vilayet of Kesh"6. It is evident that Yazdi is supporter of Timurs noble origin-he ascribed the post of amir (nobleman) to his father. Another biographer of Timur and Arab historian Ahmed Ibn 'Arabshah present some another versions of Timur's origin. According to Ibn 'Arabshah:

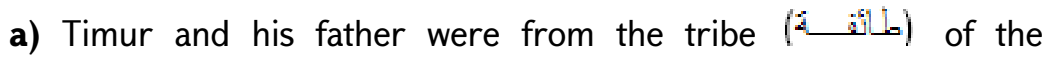

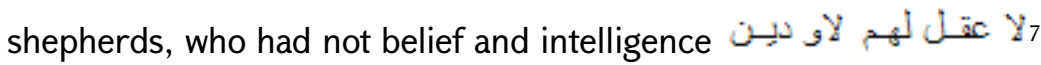

b) Timur's father was an plain servant ${ }^{8}$

c) Timurs father was a poor shoemaker ${ }^{9}$

d) Timurs father was one of the amirs of sultan Husseīn ${ }^{10}$

e) Ibn 'Arabshah considers more probable the opinion that Timur's father was an influential nobleman "he was one of the pillars of Sultan Husseīn's state" 11

This last version, ibn "Arabshah says that he has read it in the "continuation of Persian history "Muntakhab"12

${ }^{6}$ Шарафр ад-дин Али Йазди. "Зафар-наме", пер. А. Ахмедова, Ташкент, 2008, стр. 14-15.

7 Ibn 'Arabshāh, 1868, p. 6.

${ }^{8}$ Unuju untnnnuर:

${ }^{9}$ Unuju untnnnux:

${ }^{10}$ We think that ibn 'Arabshah means amir Qazaghan's grandson Hussein, because Ibn'Arabshah in same page says that the sister of this Hussein was married to Timur, and really, the sister of this Hussein Uljay Turcan ağa, daughter of amir Musla, was the wife of Timur: Bartold V., Four Studies on the History of Central Asia, transl. by V. and T. Minorsky, vol 2, Leyden, 1963, p. 17; Jamaluddin S., The state under Timur: a study in empire building, Har-Anand, 1995, p. 41.

${ }^{11}$ Ibn 'Arabshāh, 1868, p. 9-10.

12 Probably the author means the work of Mu'în al-Dîn Nạtanzî "Muntakhab altawârîkh-I Mu'îni" also known as "The anonym of Iskandar". 


\section{Russian historical}

source "Povest' o Temir Aksake" describe Timur as a cruel brigand "who hadn't noble, princely or royal origin and he was a plain smith" 14 . It is possible that this kind of information of contemporary sources let us to suppose that the stories about the "noble" origin of Timur or his father's post of amir were contrived later to ligitimise Timur's rising to the power.

It is more interesting Ibn 'Arabshah's informations about the Timur's birth. Ibn 'Arabshah writes: "They say that the night when Timur was born something has appeared, which was like an iron helmet (خوذة (خو) , which then dropped and dissolved in the space. It seemed that the sparks and incandesced coal flew and that light gathered and filled the desert and the settled places"15. Ibn "Arabshah doesn't describe this dropped thing (ســن with any word which could interpret anything. He doesn't name it a meteorite or a comet. We avoid to do quick conclusions but it is impossible to notice the circumstance that the "dropped thing" which disappeared in the space, which was like iron helmet and illuminated was described as a cosmic flying body. But is also possible that ibn 'Arabshah had described only the collapse of the comet. But here we have also some difficulties: the author didn't notice where that "thing" appeared-in the Timur's birthplace or in homeland Syria? Unfortunately we couldn't get any information about the meteorites or comets which fall in the Central Asia in the $14^{\text {th }}$ century. This is another thing if we accept the fact that it is possible that this event had taken place in ibn 'Arabshah's homeland Syria or in another part of Near East (nearer to Syria). In this case we the events which dated in 1330's. The first thing was a comet which fell in 1332 in Birgi (ancient Pirgion). Ibn Battuta who visited the beylik of Aydin and it's

\footnotetext{
13 Ibn 'Arabshāh, 1868, p. 9-10.

14 Повесть о Темир Аксаке, 'u2Ч. u2łu., $5_{2} 230$.

15 Ibn 'Arabshāh, 1868, p. 5. This description (without any commentary) is also cited from English translation of the work of ibn 'Arabshah (Tamerlane, Or Timur the Great Amir, translated by J. H. Sanders, Luzac \& Company, 1936) by Ron Sela in his valuable book "The Legendary Biographies of Tamerlane: Islam and Heroic Apocrypha in Central Asia", Cambridge University Press, 2011, p. 70.
} 
capital Birgi approximately in $1331-1332^{16}$, wrote about it. According to ibn Battuta sultan Mehmed of Aydin (Umur beg b. Muhammad, 1308-133417) asked him if he had seen a comet? When he answered that he hadn't seen, the sultan showed him the comet lied near the town ${ }^{18}$. According to The Meteoritical Society (International Society for Meteoritics and planetary Science) another collapse of comet took place in 1340 in the same region $^{19}$. It is interesting another legend of Timur's origin. According to the 2 inscriptions of Timur's mausoleum, Timur's origin linked with mythical Alan Gua and 'Ali ibn Abu Talib²0.

\section{The lameness of Timur}

Certainly, it is known that Timur was lame but the imcopatible information of the sources let us suppose that here also the realty is mixed with the myth. The principal information about it is following: when Timur attacked Sistan with amir Husseīn in 1362, he was injured with an arrow in right leg, and after that he was lame. Timur was not only lame, his right arm was harmed too. According to ibn 'Arabshah, when Timur was born his palm was "filled with blood"21. According to M. Gerasimov it was result

16 Inalcik H., The Rise of the Turcoman Maritime Principalities in Anatolia, Byzantium, and the Crusades. The Middle East \& the Balkans under the Ottoman Empire: Essays on Economy \& Society, 1993, p. 319.

17 Bosworth E., The New Islamic Dynasties: A Chronological and Genealogical Manual, Edinburgh, 2004, p. 221.

18 Ibn Battúta, Travels in Asia and Africa 1325-54, transl. and selected by H. A. R. Gibb, London, 1929, p. 134; Mohd. A. R. Khan, A Siderite of the Fourteenth Century, Nature, 154, 465-465 (07 October 1944).

${ }^{19} \mathrm{https}$ ://www.lpi.usra.edu/meteor/metbull.php?sea=Aidin\&sfor=names\&ants=\&falls $=\&$ valids $=\&$ stype $=$ contains $\& \mid r e c=50 \&$ map $=$ ge $\&$ browse $=\&$ country $=A l l \& s r t=$ name $\& c$ ateg $=$ All \&mblist=All \&rect $=\&$ phot $=\&$ snew $=0 \&$ pnt $=$ Normal $\% 20$ table $\&$ code $=420$ 20 Семенов А. 'Надписи на надгробиях Тимура и его потомков в Гур-и Эмире. Эпиграфика Востока", 1948, N 2, стр. 49-76; Denise Aigle, The transformations undergone by an original myth: the case of Chinggis Khan and Tamerlane, Revue des mondes musulmans et de la Méditerranée, N 89-90, pp. 151-168.

${ }^{21}$ Ibn 'Arabshāh, 1868, p. 5. 
of the knitting of the bones ${ }^{22}$. The fact of Timur's lameness with some differences is known in many sources. It was written in Timur's autobiographical work 'Mulzüfat" that Malik Mahmud ${ }^{23}$, the lord of Sistan, who was defoid of power, made a request for Timur to help him to return his estates and power promising to give some of them to Timur. Timur in alliance with amir Husseīn succeed to occupy some fortresses and regions. Mahmud who was afraid that Timur could take all the power and property, left Timur and then attacked him in Sistan. To all appearances Timur was defeated and injured with an arrow in the right leg and hand ${ }^{24}$. This variant is repeated almost in the same way in the Yazdi's Zafarnameh, but there was an important detail: according to Yazdī Timur was injured only in the hand ${ }^{25}$.

It is evident that Yazdi doesn't speak about the injurance in the leg. The information of Ruy Gonzalez Clavijo is a little different. According to Clavijo Timur was really injured in the right hand in Sistan, and has lost his two fingers. He was injured in the leg too, but he was injured during a clash (he wasn't injured in a battle or in a raid) when he had stolen a flock of sheep ${ }^{26}$. Ibn 'Arabshah presents the variants in this way: first he says that Timur tried to stead sheep in his youth. The shepherd noticed it and he injured Timur with an arrow-an arrow wounded the back and another arrow wounded the leg. According to the second variant Timur tried to steal sheep in Sistan to feed his friends, and the shepherd shot an arrow and wounded both hand and the leg. Moreover, after that the shepherd took Timur to the sultan of Herat Husseīn, who ordered to kill him, but

\footnotetext{
22 Герасимов М. "Портрет Тамерлана". Краткие сообщения института истории материлаьной культуры имени Н. Марра, 1947, N 17, стр. 15-16.

23 'Izz al-Din ibn Rukn al-Din Mahmud (1350-1380), Bosworth, C.E. The History of the Saffarids of Sistan and the Maliks of Nimruz (247/861 to 949/1542-3). Costa Mesa, California, 1994, p. 445.

24 The Mulfuzāt Timūr, 1830, p. 67; Тамерлан: эпоха, личность, деяния. Москва, 1992, стр. 179-180.

${ }^{25}$ Sharaf ad-din Ali Yazdi, 2008, p. 30 (see also the notice N 140).

26 Embassy to Tamerlane 1403-1406, Clavijo, London and New York, 2005 (reprint), p. 112.
} 
son of Husseinn, whose name is Ghiyath ad-dinn" saved Timur: he asked his father to give Timur him as a slave ${ }^{28}$. The information of ibn 'Arabshah about the stealing of sheep is repeated in the Russian source, which inform us that after stealing the sheep they caught, beat him and throw him to feed dogs. They also broke his leg and tigh-bone ${ }^{29}$. The source affirms in surprise that Timur reminded alive and as he was a smith, he tempered his leg with iron and after that he was called Temir Aksak-

\section{Lame Iron.}

The compatible information let us to suppose that the fact of injuring in the leg or in the arm was used later to mask his inborn defects and to present under heroic light, as a result of the injurance in the battle. M. Gerasimov noticed also that there was no trace on the leg which would be result of the injurance and it is more probably that it was an inborn defect $^{30}$.

\section{vunquกзu乙 9 १ก}

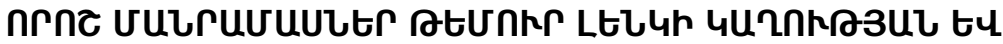 бUquUu ytruftrsuL}

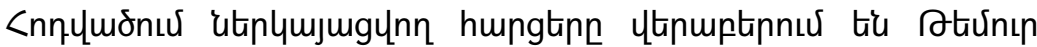

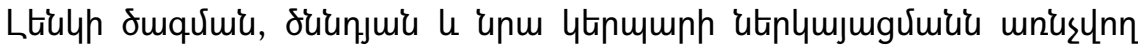

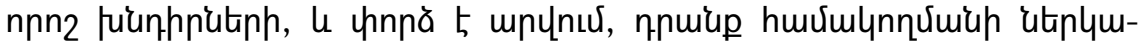

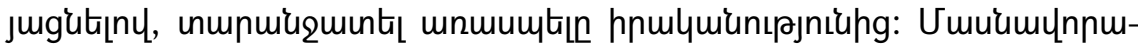

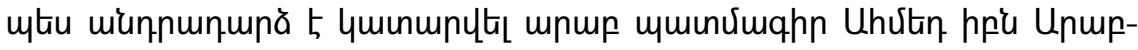

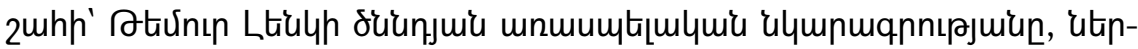

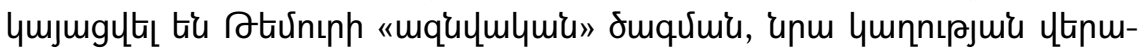

\footnotetext{
${ }^{27}$ Pir Husaīn Muhammad Kurt and his successor Ghiyāth al-Dīn II, Bosworth E., The New Islamic Dynasties: A Chronological and Genealogical Manual, Edinburgh, 2004, p. 263.

${ }^{28}$ Ibn 'Arabshāh, 1868, p. 6, 13-14.

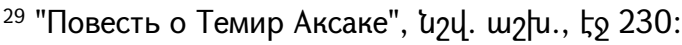

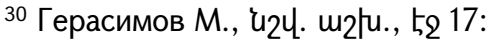




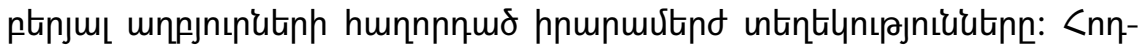

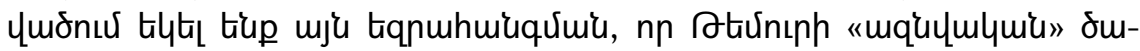

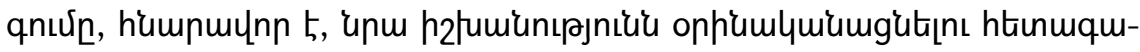

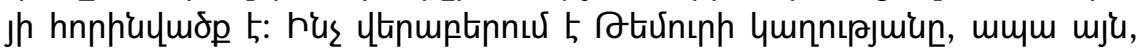

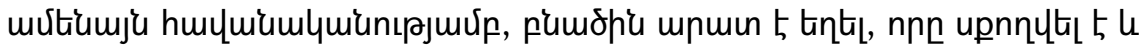

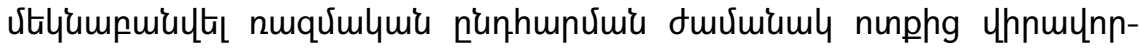

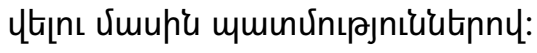

